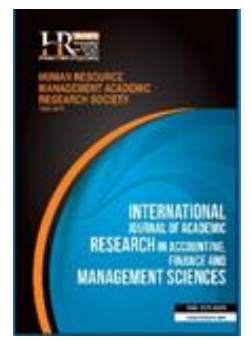

International Journal of Academic Research in Accounting, Finance and Management Sciences

Vol. 8, No.3, July 2018, pp. 149-162

E-ISSN: 2225-8329, P-ISSN: 2308-0337

(c) 2018 HRMARS

www.hrmars.com

To cite this article: Al Hayek, M.A. (2018). The Relationship Between Sales Revenue and Net Profit with Net Cash Flows from Operating Activities in Jordanian Industrial Joint Stock Companies, International Journal of Academic Research in Accounting, Finance and Management Sciences 8 (3): 149-162.

\title{
The Relationship Between Sales Revenue and Net Profit with Net Cash Flows from Operating Activities in Jordanian Industrial Joint Stock Companies
}

\author{
Mohammad Ali AL HAYEK \\ Accounting Department, Al al.Bayt University, Jordan, E-mail: mhayek30@yahoo.com
}

\begin{abstract}
The current study aims at identifying the relationship between sales revenue and net profit with net cash flows from operating activities in Jordanian industrial joint stock companies. In order to achieve this objective, the researcher conducted an analytical study based on the descriptive analytical method through the use of the statistical method to analyze the data of the study represented by the actual data taken from the relevant companies for the period (2010 - 2017). The results of the study showed the validity of hypothesis HO, "There is a statistically significant relationship between sales revenue and net profit with net cash flows from operating activities in Jordanian industrial joint stock companies".

Key words Sales revenue, net profit, Net Cash Flow from operating activities, Jordanian Industrial Joint Stock Companies

Received: 30 Aug $2018 \quad$ C The Authors 2018

Revised: 20 Sept 2018 Published by Human Resource Management Academic Research Society (www.hrmars.com)

Accepted: $\quad 30$ Sept 2018 This article is published under the Creative Commons Attribution (CC BY 4.0) license. Anyone may Published Online: 15 Oct 2018 reproduce, distribute, translate and create derivative works of this article (for both commercial and noncommercial purposes), subject to full attribution to the original publication and authors. The full terms of this license may be seen at: http://creativecommons.org/licences/by/4.0/legalcode
\end{abstract}

\section{Introduction}

Sales revenues, net profit and net cash flows from operating activities are terms that raise attention, raise questions and generate interest, as a goal of knowledge and analysis from all parties to the economic process and beneficiaries of the financial statements to ensure the continuity of economic unity and achieve profits. Sales revenues are an item of the income statement, which is the total income that the entity receives as cash flows or an increase in other assets from the main activities resulting from the exercise of its principal activity, whether from the sale of its commodity products or services. This item can be divided into other detailed items for each product or service. The net revenue is the main figure in the financial statements and is the basis for many calculations and analyzes, and an important indicator of the performance and marketing ability to sell the product.

Profit is the income earned after the deduction of all expenses. Profit is always the goal of every enterprise. As a result, many businesses are based on profit in different forms. Analysts are interested in profit before expenses, such as taxes and interest after paying all expenses. There are three main types of profit that analysts have categorized: gross profit, operating profit and net profit, and each type of profit gives more information about the company's performance. All three profit levels can be found in the income statement. Net income is used to calculate its earnings per share (EPS), and net income is the final result and is included in the last income statement.

The net cash flow from operating activities is a measure of the amount of cash generated from the Company's operating activities and operating cash flows. It is significant because it indicates whether the Company is able to generate a positive cash flow and is sufficient to meet its obligations and maintain and 
develop its operations without the need for external financing. Operating cash flows is calculating by adjusting net income by adding the recorded expenses such as depreciation and changes in current assets and liabilities. Financial analysts often rely on operating cash flow as a measure that provides a clear conception of the operating processes of the company away from the effects of certain accounting methods affecting net profit in the income statement.

The objective of the current study is to demonstrate the relationship between sales revenues and net profit with net cash flows from the operating activities of the Jordanian public joint stock companies. This is important because these variables (sales revenues, net profit, net cash flows) are important to all users of internal and external financial statements.

\subsection{Study Problem}

The continuity of any enterprise comes through the exercise of its principal operation and the achievement of operating revenues, coupled with the realized profits of positive cash flows from the operations of the enterprise. Without these cash flows, the Company will not be able to meet its outstanding obligations despite the generated profits. Net cash flows may be greater or less than net profit after tax in a company. It is also possible that a company has achieved a net loss without accompanying a surplus cash flow due to the calculation of non-cash expenses Consumption, for example, or because of a large volume of credit sales and subject to the failure of receiving part of it. The problem of the study lies in the question: "Is there a statistically significant relationship between sales revenues and net profit with net cash flows from the operating activities of Jordanian public joint stock companies" .From this mean question stem many sub-questions such as: Is there a statistically significant relationship between sales revenue, cost of sales, operating profit, net profit and net cash flows from operating activities?

\subsection{Importance of the study}

The importance of this study stems from its studying of the relationship between sales revenues and net profit with net cash flows from the operating activities of the Jordanian public joint stock companies by conducting an analytical study that adopted the descriptive analytical approach to determine the relationship between the variables of the study(2017-2010), where this subject is very important and deserves a lot of independent studies to examine all aspects related to it, to bridge the gap by determining whether there is a relationship between sales revenue and net profit with net cash flows from the operating activities of the Jordanian public joint stock companies.

\subsection{Hypotheses of the Study}

The researcher relied on the following main hypothesis to achieve the objectives of the study "HO: There is a statistically significant relationship between the sales and net profit with the net cash flows of the operating activities of the Jordanian public joint stock companies " and the following sub-hypotheses are derived from the abovementioned main hypothesis:

H01: There is a statistically significant relationship between sales revenue and net cash flows from operating activities.

H02: There is a statistically significant relationship between cost of sales and net cash flows from operating activities.

H03: There is a statistically significant relationship between operating profit and net cash flows from operating activities.

H04: There is a statistically significant relationship between net profit and net cash flows from operating activities.

\subsection{Previous studies}

This study has been linked to many previous studies in terms of its association with some variables, but not all of them. Through the lengthy research in many previous studies, I have not been able to reach any study that presented such an issue in an integrated manner in terms of studying the impact of the variables of this study on the net cash flows from activities. This study has benefited from previous studies 
in enriching some theoretical aspects and covering them and taking advantage of some common aspects between this study and previous studies. Despite the importance of previous researches and studies, studies conducted in the Jordanian environment have not addressed the subject of this area, what distinguished this study from other previous studies, especially those that were in the Jordanian environment.

Jordan et al. (2007) has studied the "An Analysis of the Comparative Predictive Abilities of Operating Cash Flows, Earnings, and And Sales" and data were collected on a randomly selected sample of 100 of the Fortune 1000 companies. The data collected included earnings, operating cash flows, and net sales for the years 2002 and 2003.The study showed that the operating cash flows provided the weakest explanatory power; both the earnings and sales models produced statistically significant results.

Martani et al. (2009) have studied the effect of financial ratios, firm size, and cash flow from operating activities in the interim report to the stock return, the study uses profitability, liquidity, leverage, market ratio, size and cash flow as proxies of accounting information. The samples of the study are in listed companies in man factoring industries that actively trading between 2003-2006 in Indonesia Stock Market. The study shows that profitability, turnover and market ratio has significant impact to the stock return.

Taani and Banykhaled (2011) have studied diversity of the correlation between stock return and financial ratios. They discussed that correlation using the data from Amman Stock Exchange. and examined is net profit margin, return on equity, current ratio, debt to equity, total asset turnover, price to book value, cash flow from operating activities, and company size, each of them has significant correlation with stock return. The study show that financial ratios, return on equity, debt to equity, price to book value, and cash flow from operating activities altogether affect earnings per share. And the variables which are consistently significant on earning per share are profitability ratio (ROE), market value ratio (PBV), cash flow from operating activities, and leverage ratio (DER).

Abd Al-Jalil (2012) examined the effect of net operating cash flows on the market share price of Jordanian industrial joint stock companies. The study included 23 Jordanian public shareholding companies listed on the Amman Stock Exchange for the year 2010. The study concluded that there was a statistically significant positive relationship between the change in the adequacy of net cash flows operational and their effectiveness, as well as the lack of interest of investors in the ASE to the adequacy and effectiveness of net operating cash flows when making the investment decision.

Al Zararee and Al-Azzawi (2014). have studied constitutes an attempt to investigate the relationship between Free Cash Flow to Equity and the firm's market value of the pharmaceutical sector of Jordan, this study used panel data covering the period 2004-2010.The results show that the Cash Flow has significant positive effect on the stock market.

Hamidi (2014) has studied the effect of operational cash flows on the value of the company by conducting a study on a sample of Iraqi private banks listed in the Iraqi Stock Exchange for the period (2008-2012) by measuring the effect of net operating flows attributable to net income, sales, total assets, short-term liabilities and equity. The dependent variable (the value of the company) was measured by the ratio of the market value of the share to the book value. The study showed that there is an impact of the operating cash flows on the value of the company.

Subatnieks (2014) has studied the relationships of cash flows from Latvian companies through establish the direction and strength of mutual relationships between different cash flow measures, and with earnings, the study show a typical Latvian enterprise relies on the operating cash flow to create the investing cash flow and does not need to rely on the external sources of financing, the study concludes the investing cash flow should be used in cash flow prediction, while it should not be used in earnings prediction.

Ball et al. (2016) have studied a cash-based measure of operating profitability that is devoid of accounting accruals adjustments and this measure significantly outperforms operating profitability in explaining the cross section of expected returns and the investors would be better off by just adding cashbased operating profitability to their investment opportunity set than by adding both accruals and profitability strategies.

Etale and Bingilar (2016) have carried out a study that included a group of companies within the banking sector listed in the Nigerian market, and found a positive effect between the cash flows and the 
value of shares in the Nigeria banking sector.The study has also indicated the importance and necessity shareholders' concentration on the cash flow statement before investing.

Foerster et al. (2016) This study relates to research that examines the relation between cash flows and the cross section of ex- pecked returns and ability of cash flows to explain average returns relative to earnings-based profitability measures. They focus on measures of free cash flow as opposed to cash-based operating profitability.

Fouad and Abouelela (2016) have aimed in their study to identify the role played by cash flows in explaining the changes in stock prices in the financial markets. The study included 154 banking institutions in Egypt during the period 2002-2009. The study found that the relationship between cash flow and net profit is related to changes in prices in the financial markets.

\section{Literature Review}

\subsection{Sales revenues}

The aim of the companies is to maximize profit at the lowest possible cost, in addition to future expansion, high sales and keeping progress ahead of competition. Sales are products provided by the sales department to be sold to the beneficiaries. The sale of more products and services means that the company is successful and progresses and enhances the wealth of the shareholders (Ajanthan, 2013). After the manufacture and delivery of the product, the company waits selling the largest quantity of it, so that the company has a certain share of the market, and determines the share of the number of competitors, and the type of the product and the public response to it.

Accounting is linked to continuous business and production processes and not to a single business operation. Accounting divides the unit's continuous activity into time segments called accounting periods, while at the same time allocating its revenues and expenses (Ball et al., 2016).

The revenue is represented by either in cash inflows, the growth of the assets of the accounting unit or in the fulfillment of its obligations or each of them through production, delivery of goods, provision of services or any other economic activity that represents the principal operations of the unit during a given period, expenses are then measured to determine the amount of income during the accounting period (AlQashi and Al-Oqlah, 2015).

International Accounting Standard 18 deals with the definition and measurement of revenue from the sale of goods, the performance of services and other revenues. The scope of this standard covers goods produced by the enterprise for sale and goods purchased with a view to resale such as goods purchased by the retailer or land or other property held for the purpose of sale, and the performance of the services usually ensures that the company performs contracted tasks during an agreed period. Services may be provided within a period or more than a period. Revenue is realized through the use of other assets of the economic unit. Revenue is defined as the total inflows of economic benefits during the period resulting from the normal activities of the enterprise and results in an increase in equity other than the increase resulting from the contributions of owners of property rights. The value of revenue resulting from a transaction is usually determined by agreement between the entity and the buyer or the user of the asset.

Revenue is recognized by transferring non-cash assets such as commodity inventory to cash or cash equivalents such receivables and also means that all operations required to earn revenue generated from the sale of a good or service have been completed, and according to the principle of revenue realization( Revenue registration time or revenue realization recognition), the Company records revenue from the sale during the period in which the majority of revenue-related activities occurred (Ball et al., 2016). As the occurrence of sales or service delivery forms an objective evidence sufficient to complete the process, and the possibility of collection of the price of the goods or service provided, this means that it is not necessary that the company collects the price of the commodity or value sold until proven as a sale or revenue, and sales and services are recognized as revenue at the time of the transaction (Al-Qashi and Al-Oqlah, 2015). The price of goods or services sold to customers is recorded as revenue for the activity in the period of sale and delivery regardless of the period in which the corresponding cash is collected (Ball et al., 2016).

Revenue is measured at fair value or at the cash equivalent of assets received in accordance with International Accounting Standards. In the case of the sale of goods or the rendering of services for goods or services that are not identical, the process is considered revenue-generating. Revenue in this case is 
measured on the basis of the fair value of the goods or services received and adjusted for any cash or cash equivalents to be exchanged. If the fair value of the goods or services cannot be reliably determined, revenue must be measured on the fair value of the goods and services that the entity relinquishes (Al-Qashi and Al-Oqlah, 2015).

\subsection{Cost of goods sold}

The cost of goods sold is one of the largest expenses to be conducted from revenue (Ball et al., 2016), and because this number is important it attracts the attention of the management and analysts. (Foerster et al., 2016). In industrial establishments, the cost of goods sold consists of the cost of finished production and is calculated by adding the cost of finished production at beginning to the total cost of production to reach the cost of the goods available for sale. The at end manufacturing includes costs associated with Production Costs of materials, wages and indirect industrial expenses .These must be charged to the producing units because they have expected future benefits to be incurred during the current period and to be loaded on other units of the period that will be available in the coming period. This cost is considered as a product cost and is described as storage costs.

\subsection{Operating profit}

Income from Main Operations is a key indicator of the overall operating performance of the company, which is particularly important as it excludes non-operating items and taxes. It is calculated after deducting operating expenses from the total profit (Ball et al., 2016). Production costs are not the only costs that the company must commit to pay to succeed, as product must be sold after its production, and of course these costs involve other expenses and costs. In addition to the marketing and advertising expenses, the company is obliged to pay the salaries of its employees, its office equipment, its administrative expenses, and the operating profit or operating loss of the company can be reached by deducting all the mentioned operating costs from the total profits.

\subsection{Net profit}

Profitability is a strategic objective pursued by economic unity. It reflects the ability of the company to invest the funds it receives from multiple sources and reduce its expenses to the extent that it achieves profits in order to maximize the wealth of the owners and to maintain the survival of the unit and its continuation (Ajanthan, 2013). Profitability represents a large number of policies and decisions. It is a general indicator of the company's profitability performance (Heikal et al., 2014). The aim of these companies is to maximize the wealth of owners by increasing profitability by investing in assets that achieve the greatest possible returns to increase the market value of its shares in the financial market (Ajanthan, 2013).

Economists were concerned with the profits of the economic-profit units as an indicator of the strength and strength of the financial economy. Financial analysts also considered these profits to be used as a tool for financial forecasting and to differentiate between a variety of investment alternatives (Foerster et al., 2016). Accountants are interested in forecasting profits in order to find the best way to enable the delivery of accounting information to their beneficiaries in order to assist economic decision makers. Profit is an important component of the financial statements of the users of the financial statements for the purpose of making investment or credit decisions (Foerster et al., 2016).

The efficiency of the economic unit is the outcome of the various policies adopted by the administration. It reflects the efficiency of its operational and investment decisions (Ajanthan, 2013). The profitability ratios measure the efficiency of the economic unit in optimizing its resources to achieve profits (Fida and Yunis, 2016) Income is an important factor in accounting because it is the main list of the project. It represents the report that measures the success of a project over a given period of time in exploiting available resources for profit, which is most useful from the point of view of investors to estimate current and future revenues, (Foerster et al., 2016), as well as the use of the information it provides to facilitate the financial analysis process, particularly those indicators associated with the profitability of the project, and to help make many economic decisions properly (Ajanthan, 2013). 
The accounting concept of income in general is the increase in benefits during the accounting cycle in the form of inflows to income or an increase in assets that result in increases in equity other than those associated with equity holders' contributions. One of the most important features of accounting income is its reliance on the actual operations of the asset, where the actual financial operations of the entity result in revenues offset by costs necessary to achieve these revenues (Ball et al., 2016). The actual operations are either external processes that are accurate and clear accounting method of accounting based on objective principles such as the acquisition of an asset by the establishment of assets or goods or services from other units, or internal operations but less accurate and objective. There are several methods to prove them as multiple ways to destroy the asset such as the allocation of a fixed asset as a result of its use, as well as its reliance on periodicity, the principle of revenue recognition, and historical cost.

The traditional concept of accounting income has been heavily criticized in the literature of accounting theory. These criticisms have been largely focused on the fact that accounting income is generally inappropriate for decision-making because it is based on historical cost without taking into account price changes (Foerster et al., 2016) .and also depends on the basis of the entitlement that is subject in some of its provisions to personal judgment, the multiplicity of accounting methods and the multiple application of accounting principles (Fida and Yunis, 2016).

Although the accounting income in the statement of income is determined by the accrual basis, it is closely related to the cash flows of the project (Fida and Yunis, 2016).It is also reflected in the form of the project's financial solvency, as well as cash flows from investments and debt. The income statement shows the entity's ability to generate profits over a certain period of time, this means that it measures the economic performance of the entity during that period but it does not show the timing of the cash flow and does not show the effect of the operations on the liquidity of the entity and its ability to repay its liabilities (Foerster et al., 2016). The cash flow statement relates to the timing of the cash flows and the sources of these flows, the liquidity of the entity and its ability to meet its obligations (Al-Ghussei\& Al-Musli, 2013).

\subsection{Cash flows from operating activities}

The cash flow statement provides information that is more reliable than the information provided by other financial statements. The statement of cash flows is considered as a record of changes in other financial statements and clearly highlights what is important to shareholders to determine available cash (Aziz, 2014). Therefore, the cash flow list is very important as it provides information on the movement of cash and sources of access and how it is spent, and the extent of change in the balance of cash between the beginning and end of the financial period (Al-Ghusein and Mosul, 2013). Because of the deficiency of income and financial statements to provide information on cash as they are calculated on the basis of accounting accrual (Ball et al., 2016), so the cash flow list comes to find out what these lists failed to provide, as it is based on the monetary basis and show the movement of in and out cash to company (Hamidi, 2014).

The importance of the cash flow statement lies in that it provides information that helps the users of the financial statements to identify the sources of cash and how to use them in the company's various activities (Al-Ghussein and Al-Musli, 2013). This helps to assess the liquidity of the company and its ability to fulfill its commitment (Gordon et al., 2017). Also, knowing the pattern and timing of cash flows, especially cash flows from operating activities, which is the result of the Company's core activity, helps predict future cash flows (Subatnieks, 2014). It also provides the basis for assessing the financial position of companies and determining their stock prices (Aziz, 2014). This list helps to compare the performance of different companies, because this list eliminates the effect of accounting adjustments that have no impact on cash flows (Hamidi, 2014).

The cash flow statement arises relatively late from the statement of income and financial position in order to provide information that it is unable to provide. These two lists are based on accounting accrual, while the cash flow statement reflects the movement of cash in and out of the Company (Hamidi, 2014).

The cash flow statement went through different stages, at each stage, a model that met the needs of its users until it stabilized as it is now in terms of content and form, in accordance with Standard No. 95 of the US Financial Accounting Standards Board (FASB) of 1987. Foerster et al. (2016) as well as the International Standard 7 of the International Accounting Standards Board (IASC) of 1992. 
Under IAS 7, the information included in the statement of cash flows should be classified into three main sections: cash flows from operating activities, cash flows from investing activities and cash flows from financing activities (Subatnieks, 2014). The cash flows into the company and the cash flows from it, and the difference between them represents the net flow. Operating activities are the revenue generating activities of the Company and are directly involved in determining the net profit or loss of the economic unit (Aziz, 2014). The importance of determining the cash flows from operating activities is to correlate the Company's continuity with positive operating cash flows for the purpose of meeting its obligations and maintaining its financial position (Foerster et al., 2016), as well as identifying the Company's operational capacity, distribution of dividends and new activities without recourse to funding sources as well as predicting future flows (Ball et al., 2016).

IAS 7 sets out two approaches to prepare a cash flow statement and extract net cash flows from operating activities, direct and indirect approaches (Hamidi, 2014.) The direct method of inclusion discloses each element of operational cash flows which helps its users to (Foerster et al., 2016.) The main difference between the two methods in preparing the cash flow statement is how to determine the net cash flows from operating activities. With regard to the calculation of net cash flow from investment and financing activities, it is similar between the two methods and there is no difference between them (Hamidi, 2014).

\section{Data Collection}

\subsection{Study population}

The study population consisted of the Jordanian industrial joint stock companies. A purposive sample consisting from the three largest Jordanian industrial companies, the Arab Potash Company, Jordan Phosphate Mines Company and Al-Iqbal Investment Company Ltd. was selected. The researcher has adopted the objectives of this study and tested its hypotheses on the actual data extracted from the annual financial reports of the relevant sample companies for the years (2010-2017).

The Arab Potash Company was established in 1956 in the Hashemite Kingdom of Jordan as a joint Arab project. The company operates under a concession from the Government of Jordan granting it the exclusive right to extract manufacture and market minerals from the Dead Sea until 2058. In addition to the company's activities in the extraction and manufacture of potash salts, the company also invests in many manufacturing and supplementary industries related to salt and minerals of the Dead Sea, including potassium nitrate, bromine and other derivatives. The Arab Potash Company is the eighth largest potash producer in the world in terms of volume and production of potash in the Arab world. The company produces potassium chloride, potassium nitrate, calcium phosphate, bromine and its derivatives. Jordan Phosphate Mines Company has 16,655,651 shares, of which 203,651 shares are for trading and nominal value per share One Jordanian Dinar (Arab Potash Company 2018).

The Jordan Phosphate Mines Company is a Jordanian joint stock company established in 1949. The company's current capital is 82.5 million dinars and aims to exploit the phosphate in Jordan. During the last six decades, the company has assumed its leading position among international companies in the fields of exploration and fertilizer industry, which is a major component of the structure of the Jordanian economy and exports. The activities of Jordan Phosphate Mines Company are within two complementary sectors namely the mining sector and the phosphate fertilizer manufacturing sector. Through the integration of the two sectors, the company has proved its strength strongly in the global markets. The company operates its production operations in the Hashemite Kingdom of Jordan, which owns the world's fifth largest phosphate reserves by 3.7 billion tons, of which 1.250 billion tons is the company's mining reserves, what makes it the world's sixth-largest phosphate producer with more than 7 million tons of phosphate per year. The company's main center is located in the capital Amman. The company also owns four mines located in the center and south of the Kingdom. These are the Rusaifa and Al Hasa mines, Al-Wadi Al-Abiyadh and the Shadia, In addition to the Research and Quality Department in the city of Rusaifa, and the industrial complex in the city of Aqaba, which aims to convert phosphate ore to products and increase the value added to it. The Industrial Complex is one of the largest phosphate fertilizer complexes in the Middle East. In addition, the company has built phosphate port in the city of Aqaba, which specializes in the export of phosphate, and will promote the export of phosphate to various international markets and is currently 
expanding and developing the industrial port and add amendments to take into account environmental issues (Jordan Phosphate Mines Company (PLC) 2018).

Al-Eqbal Investment Company was founded in 1989. Its activities include the manufacture of wellknown tobacco and cigarettes trademarks, import and export, access to commercial and industrial agencies, investment in real estate and land, construction of housing, reconstruction and renewable energy projects and branches in the Hashemite Kingdom of Jordan, United Arab Emirates and Egypt. The capital of the company is 60 million Jordanian Dinars with a nominal value of one dinar per share (Al-Eqbal Investment Co (PLC) 2018).

\subsection{Variables of the study}

To achieve the objectives of this study and to test the validity of its hypotheses, the research variables were classified and defined as follows: Independent variables: sales revenue, cost of goods sold, operating profit, net profit, and dependent variable: Net cash flows from operating activities.

\subsection{Methodology of the study}

This study adopts the analytical descriptive approach through addressing the concept of the relationship between sales revenues and net profit by net cash flows from operating activities, using the necessary scientific knowledge about the various aspects of the study by reference to previous studies and scientific references. The statistical method was used to analyze the data of the study based on the data of the relevant companies for the period (2010-2017), using descriptive statistical analysis methods to analyze the data and test hypotheses of the study.

\section{Analysis and Testing of Hypotheses}

The objective of this study is to attempt to establish the relationship between sales revenue and net profit with net cash flows from operating activities in Jordanian industrial joint stock companies during the period 2010-2017 through analyzing the data and testing hypotheses. To achieve this, three main axes were adopted:

Axis 1: The aim of this axis is to verify the appropriateness of the data for statistical analysis by identifying the extent to which the data are close to normal distribution. If these data are not distributed naturally, the necessary treatment should be performed on these data, and then Multicolinity test, autocorrelation test, and finally test Heteroskedasticity Test were used.

Axis 2: deals with the descriptive statistics of the variables of the study by using a set of descriptive statistical measures such as Mean, Standard Deviation 'Median 'Skewness 'Kurtosis ‘Maximum،Minimum.

Axis 3: aims to test the hypotheses of the study and calculate the parameters Multiple Regression Analysis.

\subsection{Test data adequacy for statistical analysis}

Before starting data analysis and testing hypotheses, it is necessary to ascertain the appropriateness of the study data for the analysis of linear regression by conducting some pre- tests. To achieve this, the following tests were performed:

Table 1. Data adequacy tests and study model

\begin{tabular}{|c|c|c|c|c|c|c|}
\hline \multirow{3}{*}{ Variables } & \multirow{2}{*}{\multicolumn{2}{|c|}{$\begin{array}{c}\text { Normal-Distribution } \\
\text { Jarque - Bera Test }\end{array}$}} & \multirow{2}{*}{\multicolumn{2}{|c|}{$\begin{array}{l}\text { Time Series } \\
\text { Stationarity }\end{array}$}} & \multirow{2}{*}{\multicolumn{2}{|c|}{$\begin{array}{c}\text { Multicollinearity } \\
\text { Collinearity Statistics }\end{array}$}} \\
\hline & & & & & & \\
\hline & J-B & Prob. & PP & ADF & VIF & Tolerance \\
\hline Sales Revenues & 2.228 & 0.328 & -12.412 & -5.125 & 2.188 & 0.658 \\
\hline Cost of goods sold & 2.036 & 0.361 & -7.042 & -4.412 & 1.695 & 0.521 \\
\hline Net Operating Income & 4.232 & 0.123 & -5.124 & -4.121 & 2.738 & 0.367 \\
\hline Net profit & 5.287 & 0.078 & -6.914 & -7.214 & 4.306 & 0.145 \\
\hline Autocorrelation Test & \multicolumn{2}{|c|}{ Durbin Watson Test } & 2.479 & & & \\
\hline $\begin{array}{l}\text { Heteroskedasticity } \\
\text { Test }\end{array}$ & \multicolumn{2}{|c|}{ White Test (Sig.) } & 0.041 & & & \\
\hline
\end{tabular}




\subsection{Normal - Distribution Test}

The Jarque-Bera test was carried out to determine whether the data are distributed in a natural way. This leads to identify the appropriate statistical method to test the hypotheses. Most of the scientific tests require that the data be distributed in a natural way. The rule of decision is to accept the null hypothesis that the data follow the natural distribution if (J-B) testing was greater than 5\% (Gujarati, 2013). This test was applied to each variable of the model. Table (1) shows that the probability of J-B testing for all model variables is greater than the significance level $(0.05 \geq \alpha)$, which means that the data are close to normal distribution.

\subsection{Test Time Series Stationarity}

Research using time series assumes the stability of these series, and autocorrelation may arise in the model when the time series on which the study is Non-Stationary (AL-Shwiyat, 2013). To verify the stability of time series, Unit Root for the Augmented non-parametic Dicky-Fuller Test (ADF) and the non-parametic Phillips-Person (PP) test of Table 1 show that the absolute value of the ADF and the non-parametic PP test are statistically significant at $(0.05 \geq \alpha)$ indicating that the time series data $(2010-2017)$ is stationary.

\subsection{Linear correlation test}

To ensure that there is no linear interference between the independent variables, which amplifies the value of the interpretation factor (R2) and makes it larger than its actual value, and cannot be considered as good for estimating the parameters (Sevu and Meshal, 2012), Collinearity Diagnostics by calculating the Tolerance for each variable of the independent model variables were carried out. Then, the study tried to find the variance inflation factor VIF. Gujarati (2013) indicated that the VIF coefficient of value 5 should not be exceeded and that the value of Tolerance should be greater than (0.05). Table (1) shows that the VIF values for all variables were greater than (1) and less than (5), ranging from (1.6) (0.658 $0.145)$, which is larger than (0.05). These values indicate that the model of the study does not suffer linear interference. The correlation between the variables is statistically significant and low, and this indicates the strength of the study model in the interpretation of the effect on the dependent variable and its identification.

\subsection{Autocorrelation test}

This test verifies that the data is free from the problem of Autocorrelation in the model, which weakens the predictability of the model. To verify this, the Durbin Watson Test (DW) was used. The value of this test is between $(0,4)$. Hussein $(2015)$ shows that the near zero result indicates a strong positive correlation between the successive numbers, and the result close to (4) indicates a strong negative correlation, but the optimal value for this test ranges from $(1.5-2.5)$. This value indicates that there is no Autocorrelation between the contiguous values of the variables. Economists are assured of their results when DW is close to (2), since the problem of self-Autocorrelation is weak (Montgomery et al., 2001) Table (1) shows that (D-W) calculated for the study model is (2.479), which is an optimal result, and indicates that the study model is free of the problem of Autocorrelation.

\subsection{Heteroscedasticity Test}

The stability of random error variation is one of the important assumptions of linear regression, and the average must be equal to zero. If random error variation is not consistent, some statistical methods are used to overcome this problem, such as the White test, which detects and treats instability at the same time. Table (1) shows that the probability of the white (0.041) is less than (5\%), indicating that the model of the study does not suffer from the problem of instability of random error variation.

\subsection{Correlation matrix}

To ensure that there is no high correlation between independent variables in the study model, which results in a distortion of the relationship between one variable and the dependent variable, (Kennedy, 1985; Anderson et al., 1993). A correlation of more than (70\%) between two independent variables or more 
is considered a high correlation. It is possible that the correlation between one of the variables and the dependent variable may result. To ensure that this problem does not exist, the correlation matrix between the independent study variables is set up, and Table 2 shows this.

Table 2. Correlation matrix to the dependent Variables

\begin{tabular}{|c|c|c|c|c|c|}
\hline Variables & & $\begin{array}{c}\text { Sales } \\
\text { Revenues } \\
\end{array}$ & $\begin{array}{c}\text { Cost of } \\
\text { goods sold }\end{array}$ & $\begin{array}{c}\text { Operating } \\
\text { Income }\end{array}$ & $\begin{array}{c}\text { Net } \\
\text { Income }\end{array}$ \\
\hline Sales Revenues & $\begin{array}{c}\text { Pearson Correlation } \\
\text { Sig. }\end{array}$ & 1 & & & \\
\hline Cost of goods sold & $\begin{array}{c}\text { Pearson Correlation } \\
\text { Sig. }\end{array}$ & $\begin{array}{l}0.584^{* *} \\
.0000\end{array}$ & 1 & & \\
\hline Net Operating Income & $\begin{array}{c}\text { Pearson Correlation } \\
\text { Sig. }\end{array}$ & $\begin{array}{c}0.487^{*} \\
0.016\end{array}$ & $\begin{array}{c}0.157^{* *} \\
0.000\end{array}$ & 1 & \\
\hline Net profit & $\begin{array}{c}\text { Pearson Correlation } \\
\text { Sig. }\end{array}$ & $\begin{array}{l}0.548 * \\
0.006\end{array}$ & $\begin{array}{c}0.263^{*} \\
0.014\end{array}$ & $\begin{array}{c}0.587^{* *} \\
0.000\end{array}$ & 1 \\
\hline
\end{tabular}

**. Correlation is significant at the 0.01 level (2-tailed).

*. Correlation is significant at the 0.05 level

The above table shows that the correlation coefficient values between the independent variables were less than $70 \%$. This indicates that there is no high correlation between the independent study variables to the extent that it can affect the results of the regression analysis and shows the accuracy and validity of the regression analysis results.

\subsection{Descriptive analysis of the study variables}

Table (3) shows the results of the descriptive analysis of the independent variables and the dependent variables during the period (2010-2017) using descriptive statistical methods of Mean, Median, Maximum, Minimum, and Std. Dev, Skewness, Kurtosis and available on the E-Views program. The results indicated that the values of the Skewness coefficients of the study variables were within the acceptable normal range of the torsion coefficients where the values were limited to $( \pm 1)$ and ranged between $(-0.27)$ for sales revenue and (0.98) for net cash flows from operating activities. Also, the kurtosis behavior of the study variables was greater than normal distribution (kurtosis $=3$ ).

Table 3. Descriptive statistics of the variables (millions)

\begin{tabular}{lccccc}
\hline Variables & $\begin{array}{c}\text { Sales } \\
\text { Revenues }\end{array}$ & $\begin{array}{c}\text { Cost of goods } \\
\text { sold }\end{array}$ & $\begin{array}{c}\text { Operating } \\
\text { Income }\end{array}$ & Net Income & $\begin{array}{c}\text { Net Cash Flow } \\
\text { from Operating } \\
\text { Activities }\end{array}$ \\
\hline Mean & 436.13 & 294.70 & 75.65 & 80.42 & 85.36 \\
\hline Median & 531.50 & 316.22 & 52.45 & 57.04 & 38.63 \\
\hline Maximum & 812.42 & 564.67 & 303.51 & 299.69 & 310.88 \\
\hline Minimum & 80.58 & 48.00 & -50.41 & 2.60 & -44.60 \\
\hline Std. Dev. & 255.91 & 182.08 & 81.26 & 70.93 & 86.34 \\
\hline Skewness & -0.27 & -0.25 & 0.87 & 0.49 & 0.98 \\
\hline Kurtosis & 3.45 & 3.44 & 3.37 & 4.61 & 5.40 \\
\hline
\end{tabular}

Source: Researcher calculations depend on E-Views out put

From the table above:

The mean of the total sales revenue was (436.13) million JOD, with a standard deviation of (255.91), indicating a difference in the value of sales revenue between the companies during the study years, where the minimum value (JOD 80.58), and the highest value (JOD 812.42) as sales revenues. 
The total average cost of goods sold in industrial companies during the study period was JOD 294.70 million, with a standard deviation of 182.08, indicating that there was dispersion in the cost of goods sold between the sample companies during the period 2010-2017. The cost of the goods sold was (48) million dinars, and the highest cost was (564.67) million dinars.

The results showed that the average gross profit was JOD (75.65) million, which constitutes an acceptable percentage of net operating profit from sales (17.34\%). The average net profit for the sample companies was $(18.44 \%)$ of sales volume. The net profit of the operations was different and the annual net profit of the companies during the period (2010-2017) which reached a standard deviation of $(81.26$ and 70.93) respectively.

Average net cash flows from operating activities in the industrial companies during the study period (2010-2017) reached an average of JOD (85.36) million, indicating that the companies have a quality in profits and ability to pay their obligations well through the main activities (86.34). This discrepancy ranged from (-4.4.60) million dinars, which is negative cash flow, and (310.88) million dinars, the highest cash flow from operating activities during the study period.

\subsection{Hypotheses Test}

Having verified the suitability of the data for statistical analysis, and carrying out a preliminary description of the study sample, the final stage of data analysis, a hypothesis test, comes. The model of the study measures the relationship between independent(Sales Revenues, Cost of goods sold, Operating Income, Net Income) and dependent variables (Net Cash Flow from Operating Activities), since the relationship between a set of independent variables and the dependent variable, the appropriate regression model for measuring this relationship is the Pooled Data Regression model. The study data are cross-sectional data, (2010-2017). In order to estimate the relationship between the variables, the E-Views program was used. The following table shows the results of the sample study:

Testing main hypothesis: this hypothesis indicates that "There is a significant relationship between Sales Revenues, Net income and Net Cash Flow from Operating Activities", In order to test this hypothesis, Pooled Data Regression was used.

Table 4. Pooled Data Regression for relationship between dependent and independent variable

\begin{tabular}{lccccc}
\hline Independent Variable & Coefficient & Std. Error & Expected sign & Z-Statistic & Prob. \\
\hline (Constant) & -10.549 & 14.685 & & -0.718 & 0.481 \\
\hline Sales Revenues & -0.987 & 0.392 & $+/-$ & -2.519 & 0.021 \\
\hline Cost of goods sold & 1.224 & 0.485 & $+/-$ & 2.523 & 0.021 \\
\hline Net Operating Income & 1.651 & 0.437 & $+/-$ & 3.781 & 0.001 \\
\hline Net Income & 0.511 & 0.220 & $+/-$ & 2.318 & 0.032 \\
\hline R & 0.940 & & & & \\
\hline R-squared & 0.883 & & & & \\
Adjusted R Square & 0.858 & & & & \\
\hline F-statistic & 35.769 & & & & \\
\hline Prob (F-statistic) & 0.000 & & & & \\
\hline
\end{tabular}

Source: Researcher calculations.

Dependent variable: Net Cash Flow from Operating Activities

Table (4) shows a statistically significant correlation at $(a \leq 0.05)$ between the independent variables combined with the net cash flows from operating activities. The correlation coefficient (94\%) is statistically significant and indicates a strong correlation. The adjusted $\mathrm{R}$ Square interprets $85.8 \%$ of the variance in the dependent variable, which means that $(85.8 \%)$ of changes in net cash flows from operating activities are due to the change in the independent variables, $(35,769)$ in statistical terms $(0.000)$. It confirms the significance of the model and indicates a statistically significant relation between the independent variables and the dependent variable. Consequently, the null hypothesis is rejected and the alternative hypothesis is accepted. 
In reviewing the results of regression coefficients, the coefficient values of all variables at different Zstatistic levels are at the level of $0.05 \alpha$ and all are less than $5 \%$. This confirms the significance of the regression coefficients and indicates that the effect of the variables is a significant effect Statistic. Hence, the multiple regression equation can be configured as follows:

$$
Y=\beta_{0}+\beta_{1} X 1+\beta_{2} X 2+\beta_{3} X 3+\beta_{3} X 4+E_{i t}
$$

Net Cash Flow from Operating Activities $=-10.549-0.987$ (Sales Revenues) +1.224 (Cost of goods sold)+ 1.651 (Net Operating Income) + 0.511 (Net Income) + 14.685

The main hypothesis is based on a set of sub-hypotheses that measure the relationship between the independent variables and the net cash flows from the operating activities of the public shareholding companies listed in the ASE during the period 2010-2017. The sub-assumptions were tested as follows:

Testing the first sub hypothesis: "There is a significant relationship between Sales Revenues and Net Cash Flow from Operating Activities"

The above table shows that the Coefficient value of the sales revenue variable is -0.987 , which is a negative value and indicates a negative relationship. This means that the higher the sales revenue the net cash flow from the operating activities in the companies decreased. In other words, the increase is one (0.987). The first hypothesis test shows that the calculated Z-Statistic value is $(-2.519)$ and is statistically significant at $95 \%$ confidence level. Probability was less than $(0.05)$ where he achieved (0.021), which means acceptance of the hypothesis that "there is a relationship with statistical differences between the sales revenue and net cash flows from operating activities".

Testing the first sub hypothesis: "There is a significant relationship between Cost of goods sold and Net Cash Flow from Operating Activities"

The above table shows that the Coefficient value of the variable cost of goods sold equals 1.224, which is a positive value and indicates a positive relationship. This means that the higher the cost of the goods sold, the higher the net cash flows from the operating activities. In other words, the cost of goods sold leads to an increase in net cash flows from operating activities by 1.224 . The second hypothesis test shows that the calculated Z-Statistic value is (2.523) and is statistically significant at 95\% confidence level. The probability came less than $(5 \%)$ where it achieved $(0.021)$, which means acceptance of the premise that provides for "there is a statistically significant difference between the costs of goods sold related to net cash flows from operating activities".

Testing the first sub hypothesis: "There is a significant relationship between Net Operating Income and Net Cash Flow from Operating Activities"

The above table shows that the Coefficient value of the net operating profit variable is 1.651 , which is a positive value and indicates a positive relationship. This means that the higher the net operating profit, the greater the net cash flow from the operating activities. In other words, the net operating profit increases net cash flows from operating activities by (1.651). The third hypothesis test shows that the calculated Z-Statistic value is (3.781) and is statistically significant at $95 \%$ confidence level. The probability was less than $(5 \%)$ where he achieved $(0.001)$, which means the acceptance of the premise that "there is a relationship between net operating profit and net cash flows from operating activities"

Testing the first sub hypothesis: "There is a significant relationship between Net Income and Net Cash Flow from Operating Activities"

The above table shows that the Coefficient value of the net profit variable is 0.511 , which is a positive value and indicates a positive relationship. The higher the net profit in the industrial companies, the greater the net cash flow from the operating activities. In other words, the increase was (0.511). The fourth hypothesis test shows that the calculated Z-Statistic value is (2.318) and is statistically significant at $95 \%$ confidence level. The probability is less than (5\%) and achieved (0.032), which means acceptance of the premise that "there is a relationship between the net profit and the net cash flows from operating activities in the Jordanian joint stock companies listed on the Amman Stock Exchange. 


\section{Results}

1. There is a significant relationship between the sales revenue and net cash flows from operating activities in Jordanian Industrial Joint Stock Companies.

2. There is a significant relationship between the cost of goods sold and net cash flows from operating activities in Jordanian Industrial Joint Stock Companies.

3. There is a relationship between net operating profit and net cash flows from operating activities in Jordanian Industrial Joint Stock Companies.

4. There is a significant relationship between Net Income and Net Cash Flow from Operating Activities in Jordanian Industrial Joint Stock Companies.

\section{Conclusions and recommendations}

The main hypothesis of the study is to identify the relationship between sales revenue, net profit and cash flows from operating activities in Jordanian industrial joint stock companies.

This is important due to the importance of the variables (sales revenue, net profit, net cash flow). To achieve this objective, the statistical method was used to analyze the data of the study represented by the actual data taken from the company's sample data for the period (2010-2017). The results of the study showed that the main hypothesis validity was statistically significant for all study variables.

\section{Recommendations}

1. The net cash flows from operating activities should be linked to net profit and sales when analyzing the liquidity of any company and its ability to meet its obligations.

2. To develop and strengthen internal control over the collection of realized revenues

3. Adopting a fiscal policy aimed at achieving growth in cash flows from operating activities.

4. To conduct further studies on the impact and relationship of study variables in companies general contribution in different sectors.

\section{References}

1. Abd AlJalil, T. H. (2012). The Effect of Net Operating Cash Flows on the Market Share Price of Jordanian General Industrial Companies, Jordan Journal of Business Administration, 153 (657), 1-23.

2. Ajanthan, A. (2013). The relationship between dividend payout and firm profitability: A study of listed hotels and restaurant companies in Sri Lanka. International Journal of Scientific and Research Publications, 3(6), 1-6

3. Al Zararee, A. N., \& Al-Azzawi, A. (2014). The impact of free cash flow on market value of firm. Global Review of Accounting and Finance, 5(2), 56-63.

4. Al-Eqbal Investment Co (PLC) www.eqbal-invest.com

5. Al-Ghussain, R., \& M Al-Musli, M. (2013), the importance of the measures of cash flows in investment decision-making in Damascus Stock Exchange (Applied Study), Tishreen University Journal for Research and Scientific Studies -Economic and Legal Sciences Series Vol. (35) No. (2),

6. Al-Qashi, Z. S., \& Al-Aqlah, M. (2015) The Impact of Compliance of Revenue Recognition Principle on the Problems of Income Resources in Arab Satellite Channel Measuring. Algerian Journal of Accounting and Financial Studies Issue 1, 2015

7. AL-Shwiyat, Z.., ALRjoub, A. M., \& Bshayreh, M. (2013), The impact of Social Responsibility on the Financial Performance for Jordanian Companies, European Journal of Business and Management, Vol.5, No.30.

8. Anderson, D.R., Sweeney, D.R. and Williams, T.A. (1993), Statistics for Business and Economics, Fifth Edition, West Publishing Company, St. Paul, MN

9. Annual reports of Jordanian industrial companies of the years 2010-2017.

10.Arab Potash Company http://www.arabpotash.com

11.Aziz, K. A. (2014). The role of predicting financial failure and operational cash flow indicators in banking stability using an applied study in a sample of Iraqi banks listed in the Iraqi Stock Exchange Kida model. Al-Ghari Journal of Economic and Administrative Sciences, 10 (30), 312-342. 
12.Ball, R., Gerakos, J., Linnainmaa, J. T., \& Nikolaev, V. (2016). Accruals, cash flows, and operating profitability in the cross section of stock returns. Journal of Financial Economics, 121(1), 28-45.

13.Etale, L. M., \& Bingilar, P. F. (2016). The Impact of Cash Flow on Stock Price in the Banking Sector of Nigeria. Business, Management and Economics Research, 2(7), 136-140.

14.Fida, A. O., \& Younis, A. A. (2016). The quality of profits and their impact on the financial statements. Journal of Baghdad College of Economic Sciences, (48), 249-264.

15.Foerster, S., Tsagarelis, J., \& Wang, G. (2016). Are Cash Flows Better Stock Return Predictors Than Profits?. Financial Analysts Journal, 73(1), 73-99.

16.Fouad , O, M,. Abouelela, M. (2016). Analytical Study for the Information Content of Cash Flows Statement and Accounting Earning on the Stock Market Activity Applied Study on Banking Sector in Egypt , Proceedings of 11th Annual London Business Research Conference, Imperial College, London, UK ,ISBN: 9781-925488-11-1.

17.Gordon, E. A., Henry, E., Jorgensen, B. N., \& Linthicum, C. L. (2017). Flexibility in cash-flow classification under IFRS: determinants and consequences. Review of Accounting Studies, 22(2), 839-872.

18.Gujarati, D. N. (2013), Basic Econometrics, seventh Edition, McGraw-Hill.

19. Hamidi, K. S. A. (2014). Effect of operational cash flows on the value of the company - A practical study in a sample of Iraqi private banks listed in the Iraqi market for securities. Al-Muthanna Journal of Administrative and Economic Sciences 3 (7), 65-87.

20. Heikal, M., Khaddafi, M., \& Ummah, A. (2014). Influence analysis of return on assets (ROA), return on equity (ROE), net profit margin (NPM), debt to equity ratio (DER), and current ratio (CR), against corporate profit growth in automotive in Indonesia Stock Exchange. International Journal of Academic Research in Business and Social Sciences, 4(12), 101.

21.Hussein, H. B. (2015), Data Analysis Using the Statistical Package for Social Sciences, First Edition, Dar Wael Publishing and Distribution, Amman, Jordan.

22.International Accounting Standard Board (IASB) iasb www.ifrs.org

23.International Financial Report Standards (IFRS) http://www.ifrs.org

24.Jordan Phosphate Mines Company (PLC) https://www.jpmc.com.jo

25.Jordan, C. E., Waldron, M. A., \& Clark, S. J. (2007). An analysis of the comparative predictive abilities of operating cash flows, earnings, and sales. Journal of Applied Business Research, 23(3), 53.

26.Jordanian Companies Law No. (22) of 1997 and its amendments.

27.Kennedy, P., (1985), A Guide to Econometrics, Second Edition, Basil Blackwell Ltd, Oxford.

28.Martani, D., Khairurizka, R., \& Khairurizka, R. (2009). The effect of financial ratios, firm size, and cash flow from operating activities in the interim report to the stock return. Chinese Business Review, 8(6), 44-55.

29.Montgomery, D. C., Peck, E. A., and Vining, G. G. (2001), Introduction To Liner Regression Analysis, 3th Edition, New York, $N$ Y: John Wiley \& Sons.

30.Nguyen, T., Cai, C. X., \& McColgan, P. (2017). How firms manage their cash flows: an examination of diversification's effect. Review of Quantitative Finance and Accounting, 48(3), 701-724

31.Seifu, W. I., \& Meshaal, A. M. (2012), Analytical econometrics between theory and practice , 3rd Edition, Dar Majdalawi Publishing and Distribution, Amman, Jordan.

32.Subatnieks, K. (2014). The relationships of cash flows: evidence from Latvian companies. Ekonomika.

33.Taani, K. Banykhaled, M. (2011). The effect of financial ratios, firm size and cash flows from operating activities on earnings per share:(an applied study: on Jordanian industrial sector). International journal of social sciences and humanity studies, 3(1), 197-205. 